\title{
Apakah Beban Kerja, Stres Kerja dan Kualitas Tidur Mempengaruhi Kelelahan Kerja pada Perawat di Rumah Sakit?
}

\author{
Ni Wayan Dimkatni ${ }^{1}$, Oksfriani Jufri Sumampouw ${ }^{1}$, Aaltje Ellen Manampiring ${ }^{2}$ \\ ${ }^{1}$ Program Pascasarjana Ilmu Kesehatan Masyarakat Universitas Sam Ratulangi \\ ${ }^{2 \cdot}$ Fakultas Kedokteran Universitas Sam Ratulangi \\ E-mail: niwayandimkatni@gmail.com
}

\begin{abstract}
Background: Work fatigue is a feeling of fatigue and a decrease in alertness. The word fatigue indicates a different state of the body but all of them result in a decrease in work power and a decrease in the body's resistance to work. Work fatigue factor, contributes 50\% or more to work accidents. This study aims to determine the correlation between workload, job stress and sleep quality with work fatigue on nurses in The Regional General Hospital of Bitung City and Budi Mulia Hospital Bitung City. Method: This study used cross sectional design. Respondents in this study were nurses who worked at Intensive Care Unit, Emergency Room and Inpatien Room in The Regional General Hospital of Bitung and Budi Mulia Hospital Bitung North Sulawesi Province. The instrument of this study used questionnaire. Results: The results showed there was correlation between workload $(p=0.000)$, job stress $(p=0.000)$ and sleep quality $(p=$ 0.002) with work fatigue. Multivariate analysis showed that the variable most correlated to work fatigue is job stress $(\beta=0.370)$. Conclusion: The conclusion in this study there was a correlation between workload, job stress, sleep quality with work fatigue on nurses in the Hospital. Job stress was the most correlated factor to work fatigue on nurses in the Hospital.
\end{abstract}

Keywords: nurses, fatigue, Bitung city, hospital

\section{PENDAHULUAN}

Kesehatan dan keselamatan kerja merupaka suatu usaha dan upaya untuk menciptakan perlindungan dan keamanan dari resiko kecelakaan dan bahaya fisik, mental maupun emosional terhadap pekerja, perusahaan, masyarakat dan lingkungan. Ketentuan mengenai kesehatan dan keselamatan kerja telah diatur sedemikian rupa, tetapi dalam praktiknya tidak seperti yang diharapkan . begitu banyak faktor di lapangan yang mempengaruhi kesehatan dan keselamatan kerja seperti faktor manusia, lingkungan dan psikologis (Sucipto, 2014). Kelelahan adalah kondisi berbeda-beda yang dirasakan setiap individu, walaupun berbeda-beda tetapi tetap semuanya berpusat pada kehilangan efisiensi dan penurunan kapasitas kerja serta ketahanan tubuh (Tarwaka, $d k k$. 2004). Kelelahan dapat terjadi sebagai akibat dari berbagai faktor yang mungkin berhubungan dengan pekerjaan, gaya hidup, atau kombinasi keduanya (Kuswana 2017). 
International Labour Organization (2014) menetapkan bahwa pekerja harus dilindungi dari penyakit dan cedera yang timbul dari pekerjaan mereka. ILO memperkirakan bahwa 2,02 juta orang meninggal setiap tahun karena kecelakaan atau penyakit terkait pekerjaan. Lebih lanjut 317 juta orang menderita penyakit yang berhubungan dengan pekerjaan, dan diperkirakan ada 337 juta kecelakaan yang terkait dengan pekerjaan fatal dan tidak fatal per tahun (ILO, 2014). Kelelahan kerja merupakan faktor yang memberikan kontribusi sebesar 50\% bahkan lebih terhadap terjadinya kecelakaan kerja. (Mauritis, 2013). Kelelahan juga terlibat dalam 20\% kecelakaan di jalan-jalan utama dan dikatakan menelan biaya $£ 115-240$ juta per tahun di Inggris untuk kecelakaan kerja saja (HSE, 2019).

Rumah Sakit Umum Daerah Bitung (RSUD) dan Rumah Sakit Budi Mulia merupakan rumah sakit tipe $\mathrm{C}$ selain menjadi pusat rujukan kesehatan dari Puskesmas di Kota Bitung, kedua rumah sakit ini melayani masyarakat dari luar daerah yang datang melalui Pelabuhan Samudera Bitung dan Kabupaten sekitarnya seperti Kabupaten Minahasa Utara, oleh karena itu pasien yang berkunjung di 2 Rumah Sakit ini cukup banyak. Tujuan penelitian ini yaitu untuk mengetahui hubungan antara beban kerja, stres kerja dan kualitas tidur dengan kelelahan kerja pada perawat di RSUD Bitung dan RS Budi Mulia Bitung.

\section{METODE PENELITIAN}

Penelitian ini merupakan penelitian korelasional menggunakan rancangan cross sectional. Tempat penelitian di Instalasi Gawat Darurat (IGD), Intensive Care Unit (ICU), dan Rawat Inap di RSUD Bitung dan Rumah Sakit Budi Mulia Bitung. Populasi Perawat yang bekerja di IGD, ICU dan Rawat Inap di RSUD Bitung dan Rumah Sakit Budi Mulia Bitung yang berjumlah 175 orang perawat. Variabel bebas yaitu beban kerja, stres kerja, kualitas tidur dan variabel terikat yaitu kelelahan kerja. Analisis bivariat menggunakan uji korelasi Spearman rho. Analisis multivariat menggunakan regresi linier untuk mengetahui variabel mana yang paling berpengaruh terhadap kelelahan kerja.

\section{HASIL DAN PEMBAHASAN}

\section{Analisis Univariat}

Analisis univariat menjelaskan tentang sebaran karakteristik responden berdasarkan umur, jenis kelamin, tingkat pendidikan dan status pernikahan. Karakteristik responden dapat dilihat pada Tabel 1.

Tabel 1. Karakteristik Responden

\begin{tabular}{clrrrr}
\hline $\begin{array}{c}\text { Karakteristik } \\
\text { Responden }\end{array}$ & \multicolumn{1}{c}{ Kategori } & $\begin{array}{c}\text { RSUD } \\
\text { Bitung }\end{array}$ & $\begin{array}{c}\text { RS } \\
\text { Budi } \\
\text { Mulia }\end{array}$ & N & \% \\
\hline & 17-25 Tahun & 26 & 18 & 44 & 25.1 \\
Umur (tahun) & 26-35 Tahun & 77 & 26 & 103 & 58.8 \\
& 36-45 Tahun & 18 & 3 & 21 & 12 \\
& 46-55 Tahun & 4 & 2 & 6 & 3.4 \\
& 55-65 Tahun & 1 & 0 & 1 & 0.5 \\
\hline \multirow{2}{*}{ Jenis kelamin } & Laki-laki & 20 & 6 & 26 & 14.9 \\
& Perempuan & 106 & 43 & 149 & 85.1 \\
\hline \multirow{2}{*}{ Tingkat } & SMA & 2 & 1 & 3 & 1.7 \\
Pendidikan & D3 & 73 & 40 & 113 & 64.6 \\
& S1 & 51 & 8 & 59 & 33.7 \\
\hline Status & Belum menikah & 47 & 27 & 74 & 42.3 \\
pernikahan & Menikah & 79 & 22 & 101 & 57.7 \\
\hline
\end{tabular}


Tabel 1 menunjukkan bahwa responden terdistribusi paling banyak pada kelompok umur 26-35 tahun (58.9\%), jenis kelamin perempuan (85.1\%), berpendidikan D3 (64.6\%), dan sudah menikah (57.7\%). Distribusi responden berdasarkan beban kerja, beban kerja, stress kerja, stress kerja, kualitas tidur dan kelelahan kerja dapat dilihat pada Tabel 2.

Tabel 2. Distribusi responden

\begin{tabular}{clrrrr}
\hline Variabel & Kategori & RSUD & Budi Mulia & \multicolumn{1}{c}{ Total } & \multicolumn{1}{c}{$\%$} \\
\hline \multirow{5}{*}{ Beban kerja } & Ringan & 57 & 20 & 77 & 44 \\
& Sedang & 67 & 29 & 96 & 54.9 \\
& Berat & 2 & 0 & 2 & 1.1 \\
& Total & 126 & 49 & 175 & 100 \\
\hline \multirow{3}{*}{ Stres kerja } & Rendah & 74 & 17 & 91 & 52 \\
& Tinggi & 52 & 32 & 84 & 48 \\
& Total & 126 & 49 & 175 & 100 \\
\hline \multirow{3}{*}{ Kualitas Tidur } & Baik & 34 & 19 & 53 & 30.3 \\
& Buruk & 92 & 30 & 122 & 69.7 \\
& Total & 126 & 49 & 175 & 100 \\
\hline & Ringan & 48 & 7 & 55 & 31.4 \\
& Sedang & 76 & 41 & 117 & 66.9 \\
& Tinggi & 2 & 1 & 3 & 1.7 \\
& Total & 126 & 49 & 175 & 100 \\
\hline
\end{tabular}

Tabel 2 menunjukkan bahwa beban kerja terbanyak berada dalam kategori sedang berjumlah $54.9 \%$, beban kerja ringan berjumlah $44 \%$ dan beban kerja berat berjumlah $1.1 \%$. Stres kerja dikategorikan menjadi stres kerja rendah dan stres kerja tinggi. Selanjutnya, responden dengan stres kerja rendah berjumlah $52 \%$, responden dengan stres kerja tinggi berjumlah $48 \%$. Kualitas tidur dibagi menjadi 2 kategori yaitu kualitas tidur baik dan kualitas tidur buruk. Kualitas tidur baik 30.3\% dan kualitas tidur buruk memiliki jumlah paling banyak yaitu $69.7 \%$. Kelelahan kerja dikategorikan menjadi Ringan, Sedang, Tinggi. Kelelahan kerja ringan berjumlah $31.4 \%$, responden dengan kelelahan kerja sedang berjumlah $66.9 \%$, responden dengan kelelahan kerja tinggi berjumlah $1.7 \%$.

\section{Analisis Bivariat}

Hasil analisis bivariat hubungan antara beban kerja, stres kerja dan kualitas tidur dengan kelelahan kerja dapat dilihat pada tabel 3.

Tabel 3. Hubungan antar variabel

\begin{tabular}{lrrl}
\hline Variabel & \multirow{2}{*}{ Koefisien Korelasi } & p-value & $\begin{array}{l}\text { Arah } \\
\text { Korelasi }\end{array}$ \\
\hline Beban Kerja & 0.349 & 0.000 & Positif \\
Stres Kerja & 0.264 & 0.000 & Positif \\
Kualitas Tidur & 0.232 & 0.002 & Positif \\
\hline
\end{tabular}

Hasil penelitian menunjukan bahwa beban kerja memiliki hubungan signifikan dengan kelelahan kerja dengan $p$ value $=0.000$ dengan koefisien korelasi $\mathrm{r}=0.349$ menunjukan keeratan hubungan yang lemah antara beban kerja dengan kelelahan kerja dengan arah korelasi positif. Penelitian yang dilakukan oleh Perwitasari dan Tualeka (2014) menunjukan hasil yang sama bahwa terdapat hubungan antara beban kerja dengan kelelahan kerja. Hasil penelitian ini sejalan dengan penelitian yang dilakukan oleh Uli (2018) tentang Factors Related to Fatigue among Nurses in Jambi Mental Hospital: A 2017 Study yang bertujuan untuk mengetahui faktor-faktor yang 
berhubungan dengan kelelahan pada perawat di ruang rawat inap Rumah Sakit Jiwa Jambi, data dikumpulkan melalui tinjauan literatur dan studi lapangan dalam bentuk observasi dan wawancara perawat di ruang rawat inap, hasil penelitian menunjukan bahwa terdapat hubungan antara beban kerja dengan kelelahan kerja.

Penelitian yang dilakukan oleh Tenggor (2019) dengan judul faktor-faktor yang berhubungan dengan kelelahan kerja pada perawat di ruangan rawat inap Pancaran Kasih Manado sejalan dengan hasil penelitian di atas bahwa ditemukan adanya hubungan antara beban kerja dengan kelelahan kerja. Penelitian yang dilakukan oleh Wiyarso (2018) juga menemukan bahwa terdapat hubungan antara beban kerja dengan kejadian kelelahan kerja, hal ini dikarenakan ketika beban kerja meningkat maka kemampuan bekerja semakin melemah. Beban kerja yang terjadi pada perawat dikedua rumah sakit ini termasuk dalam kategori sedang dengan aktivitas yang dilakukan seperti mengerjakan tugas administrasi, pemasangan infus, observasi pasien, memberi suntikan pada pasien, menyiapkan tempat tidur, mengukur suhu tubuh, mengukur tekanan darah pasien, streilisasi alat kesehatan, menyiapkan tempat tidur. Beban kerja yang tidak sesuai dengan kapasitas kerja seseorang, akan menyebabkan kelelahan kerja.

Stres kerja memiliki hubungan yang signifikan dengan kelelahan kerja dengan nilai $p$-value 0,000 dan memiliki koefisien korelasi $\mathrm{r}=0.264$ menunjukan adanya hubungan antara stres kerja dengan kelelahan kerja dengan arah positif dan keeratan hubungan lemah. Hasil uji statistik menunjukan terdapat hubungan antara stres kerja dengan kelelahan kerja pada perawat di RSUD Bitung dan RS Budi Mulia Bitung. Penelitian Kirana dan Dwiyanti (2017) tentang hubungan stres kerja dengan kelelahan kerja perawat dengan metode dass 21 dan IFRC menunjukan adanya hubungan antara stres kerja dengan kelelahan kerja. Penelitian oleh Dewi (2016) tentang stres kerja, usia, dan lama layanan dengan kelelahan kerja pada perawat di rumah sakit jiwa Grhasia Yogyakarta sejalan dengan hasil penelitian ini yaitu terdapat hubungan antara stres kerja dengan kelelahan kerja, hal ini disebabkan karena tubuh kita akan mengaktifkan respons melawan atau menghindar dalam keadaan stres, baik kita memilih untuk tetap aktif maupun diam. Akibatnya kita mengeluarkan lebih banyak energi, dan hal ini dapat menyebabkan kelelahan (NSF, 2004).

Berbeda dengan penelitian yang dilakukan pada perawat Perawat ICU Rumah Sakit Imanuel Bandung hasil penelitian menunjukan tidak terdapat hubungan antara stres kerja dengan kelelahan kerja. Stres kerja dan kelelahan kerja responden berada pada tingkat ringan hal ini disebabkan karena dilihat dari masa kerja responden di rumah sakit ini sebagian besar memiliki masa kerja $>5$ tahun sehingga memiliki pengalaman kerja yang lama semakin lama pengalaman kerja seseorang maka kemampuan seseorang dalam menghadapi masalah ditempat kerja semakin baik (Kurnia $d k k$, 2015). Tubuh dalam keadaan stres mengaktifkan respon dan mengeluarkan energi lebih banyak yang berdampak pada kejadian kelelahan kerja. Stres kerja penting untuk diperhatikan karena dapat menyebabkan kelelahan kerja yang berdampak pada produktivitas kerja, motivasi kerja perawat, maupun tingkat kehadiran perawat, jika perawat bekerja dengan nyaman terjamin keselamatan dan kesehatan kerja maka pekerjaan yang dilakukan akan berhasil dengan baik yang berdampak pula pada kesehatan pasien dan instansi tempat perawat bekerja.

Variabel kualitas tidur memiliki $p$ value $=0.002$ dan nilai koefisien korelasi $=0.232$ dengan arah positif menunjukan bahwa terdapat hubungan yang siginifikan dengan keeratan hubungan lemah antara kualitas tidur dengan kelelahan kerja. Penelitian ini sejalan dengan penelitian yang dilakukan oleh Idris (2014) tentang hubungan kualitas tidur, shift kerja dengan kelelahan perawat di instalasi rawat inap RSUD Kota Bekasi dengan hasil terdapat hubungan antara kualitas tidur dengan kelelahan kerja. Penelitian tentang kualitas tidur dan kelelahan kerja pada perawat di Rumah Sakit Umum Daerah 
Cibinong, menunjukan adanya hubungan antara kualitas tidur dengan kelelahan kerja, perawat dengan hasil kualitas tidur buruk lebih beresiko mengalami kelelahan kerja (Rizky dan Hendra, 2017). Perawat pada umumnya memiliki jadwal kerja yang tidak beraturan, adanya shift kerja ini menyebabkan pola tidur yang berubah-ubah pada perawat sehingga terjadi penurunan kualitas tidur yang berdampak pada kelelahan kerja. Kualitas tidur yang buruk juga dapat menyebabkan penurunan konsentrasi, penurunan daya tahan tubuh, hasil kerja kurang maksimal. Tidur yang cukup sangat diperlukan oleh perawat agar tidak terjadi kelelahan kerja.

Analisis Multivariat

Analisis multivariat dilakukan untuk melihat variabel mana yang paling berpengaruh dan besaran pengaruh. Hasil analisis multivariat dapat dilihat pada tabel 4 . Tabel 4. Hasil Analisis Multivariat

\begin{tabular}{crrr}
\hline Variabel & Coefisien Beta & Beta & Sig \\
\hline Beban Kerja & 1.469 & 0.228 & 0.001 \\
Stres Kerja & 0.450 & 0.370 & 0.000 \\
Kualitas Tidur & 0.496 & 0.133 & 0.053 \\
\hline
\end{tabular}

Hasil uji multivariat di atas didapatkan bahwa variabel stres kerja dengan nilai Beta $=0.370$ merupakan variabel yang paling dominan berhubungan dengan kelelahan kerja. Stres di tempat kerja sering dialami oleh perawat karena setiap hari perawat menangani pasien dengan keluhan yang berbeda, situasi pekerjaan dan kemampuan dalam menghadapi tekanan di tempat kerja merupakan faktor pemicu adanya stres di tempat kerja, akibatnya kita mengeluarkan lebih banyak energi, dan hal ini dapat menyebabkan kelelahan.

\section{PENUTUP}

Kesimpulan penelitian ini yaitu terdapat hubungan antara beban kerja, stres kerja dan kualitas tidur dengan kelelahan kerja kerja pada perawat. Stres kerja merupakan faktor yang paling dominan berhubungan dengan kelelahan kerja kerja pada perawat di RSUD Bitung dan RS Budi Mulia Bitung. Berdasarkan hasil penelitian ini maka perlu dilaksanakan upaya peningkatan pengetahuan dan keterampilan tentang kesehatan dan keselamatan kerja. Bagi pekerja diharapkan untuk lebih memperhatikan kesehatan dan keselamatan di tempat kerja serta memperhatikan kualitas tidur untuk meningkatkan produktivitas kerja.

\section{DAFTAR PUSTAKA}

Dewi, A., A. Surono dan A. Sutomo. 2016. Stres Kerja, Usia dan Lama Layanan dengan Kelelahan Kerja pada Perawat di Rumah Sakit Jiwa Grhasia. Berita Kedokteran Masyarakat. 32(2) Tahun 2016

Health and Safety Executive. 2019. Human Factors Fatigue. London

Idris, M. 2014. Hubungan kualitas tidur shift kerja dengan kelelahan perawat di instalasi rawat inap RSUD Kota Bekasi.

International Labour Organization. 2014. Rules of The Game A brief introduction to International Labour Standards. Swiss: ILO

Kirana, Vdan E. Dwiyanti. 2017. Hubungan Stress Kerja dengan Kelelahan Kerja pada Perawat dengan Metode Pengukuran Dass 21 dan IRFC. Jurnal Ilmiah Kesehatan Husada. 6(1).

Kurnia, HK., N. dan L. Hotmaida. 2015. Hubungan Tingkat Stres Kerja dengan Tingkat Kelelahan Kerja Peraat ICU Rumah Sakit Immanuel Bandung. Immanuel Jurnal Ilmu Kesehatan. 9(1), Juni 2015

Kuswana, W. 2017. Ergonomi dan K3 . Bandung: PT. Remaja Rosdakarya 
Mauritis, L. S. K. 2013. Selintas Tentang Kelelahan Kerja. Jakarta: Amara Books

National Safety Council. 2004. Manajemen Stress. Jakarta: EGC

Perwitasari, D. dan A. Tualeka.2014. Faktor yang Berhubungan dengan Kelelahan

Kerja Subyektif pada Perawat di RSUD DR. Mohamad Soewandhie Surabaya.

The Indonesian Journal of Occupational Safety, Health and Environment. 1(1): $15-23$

Rizky,K., and Hendra. 2017. Correlation of Sleep Quality and Perceived Fatigue Among Nurses at the Cibinong Regional Public Hospital, 2017. International Conference of Occupational Health and Safety (ICOHS-2017) Volume 2018

Sucipto, C. 2014. Keselamatan dan Kesehatan Kerja. Yogyakarta: Gosyen Publishing

Tenggor, D., L. Pondaag dan R. S. Hamel. 2019. Faktor-faktor yang Berhubungan dengan Kelelahan Kerja pada Perawat di Rawat Inap Rumah Sakit Umum Pancaran Kasih Manado. e-Journal Keperawatan (e-Kp). 7(1), Mei 2019

Tarwaka, S., H. Bakri dan L. Sudiajeng. 2004. Ergonomi untuk Keselamatan Kesehatan Kerja dan Produktivitas. Surakarta: UNIBA Press

Uli, R., R. Modjo and Turdinanto. 2018. Factors Related to Fatigue among Nurses in Jambi Mental Hospital: A 2017 Study.ICOHS 2017 International Conference of Occupational Health and Safety (ICOHS-2017). Volume 2018

Wiyarso, J. 2018. Hubungan antara Shift Kerja dan Beban Kerja dengan Kelelahan Kerja pada Perawat di Ruang Rawat Inap Yeheskiel dan Hana di Rumah Sakit Umu GMIM Pancaran Kasih Manado. Jurnal KESMAS. 7(5), 2018 